\title{
The Effect of Vacuum Assisted Closure Dressing Technique versus Conventional Dressing on Diabetic Foot Wound Healing
}

\author{
Hend Abdel Monem Elshenawie, Lecturer \\ Medical Surgical Nursing, Faculty of Nursing, Alexandria University \\ Soheir Weheida, Professor \\ Medical Surgical Nursing, Faculty of Nursing, Alexandria University \\ Aziza El Said, Teacher \\ Medical Surgical Nursing, Institute of Nursing, Alexandria University
}

\begin{abstract}
Diabetic foot ulcers affect millions of people in all the world and impose tremendous medical, psychosocial and financial loss. They also represent a major use of health resources, incurring costs not only for dressings, but also staff costs (for podiatrists, nurses, doctors), tests and investigations, antibiotics and specialist foot wear. Therefore, nurses need up to date knowledge concerning managing wounds with using appropriate strategies to control infection, promote wound healing and prevent recurrence to ensure successful out comes for those patients. Negative pressure wound therapy (NPWT) is generally well tolerated and appears to stimulate a granulation tissue response compared with other wound healing modalities. This device may be a cost-effective adjunctive wound healing therapy. Objective: Determine the effect of vacuum assisted closure dressing technique versus conventional dressing on diabetic foot wound healing: the present study follows aquasi-experimental research design. Setting: The study was conducted at Diabetic Foot Care Unit of Alex University and Royal Vascular Center. Subjects: The study was conducted on a convenient sample of 40 patients, who were divided into two sequential groups. One group received VAC dressing while the other group received conventional saline moistened gauze dressing. Tools: Tool I: Diabetic Foot Wound Assessment Structural Interview Schedule and Tool II: Wound Healing Assessment Observational Checklist. Results: There was a statistically significant difference in the rate of appearance of granulation tissue between the two groups; with granulation tissue appearing earlier in the study group. The study group promised a better outcome as compared to the control group. Conclusion: Using of $V A C$ therapy yield improved wound healing in comparison to their control in patient with diabetes mellitus more over the majority of studied patients who had faster and more effective wound healing. Recommendations: Study of the effect of VAC therapy on infected diabetic wound healing VAC therapy should be used in all grades of diabetic foot wound.
\end{abstract}

Keywords: Vacuum Assisted Closure Dressing, Diabetic Foot.

\section{Introduction}

Diabetes is increasingly becoming a major chronic disease burden all over the world. The cost of treatment of the various complications of diabetes is increasingly higher. This requires a shift in healthcare priorities in all regions of the world to help plan and prioritize health programs. Diabetes mellitus is a serious health problem because of the associated glucoserelated complications of the disease, including the specific 'microvascular' complications such as retinopathy, nephropathy and neuropathy. Coupled with this, insulin resistance increases the risk of macrovascular complications including cardiovascular, cerebrovascular and peripheral arterial disease (PAD) as well as neuropathy which can occur separately, or 
in combination. Foot ulceration is reported to affect $15 \%$ or more of people with diabetes mellitus $\mathrm{M}$ at some time in their lives $^{(1,2)}$. Estimates of the prevalence of foot ulceration vary, but around $1 \%$ to $4 \%$ of people with diabetes mellitus have foot ulcers at any given time ${ }^{(3,4)}$. A person with diabetes mellitus in receipt of US Medicare, the prevalence of the presence of least one foot ulcer was $8 \%{ }^{(5)}$.

The particular combination of peripheral neuropathy and peripheral vascular disease contributes to the development of foot ulceration, which may lead to surgical debridement or amputation of the foot or lower limb. Diabetic foot disorders such as ulceration, infection and gangrene are the most common complications associated with the disease. The most superficial wounds, has a complex in its treatment and is often with poor healing responses and high rates of complications $^{(6,7)}$, which leads to no healing, or difficulty to treat. Moreover, diabetic foot wounds are significant considered risk factors for non-traumatic foot amputations for individuals with diabetes. No doubt, foot wounds in people with diabetes mellitus have a serious impact on health related quality of life, particularly with respect to physical functioning and role limitations due to physical and emotional issues $^{(7)}$.

The Wagner wound classification system was one of the first described and has, historically, been widely used, although it is now rarely used in clinical practice. This system assesses ulcer depth and the presence of osteomyelitis or gangrene and graded them as: grade 0 (pre- or postulcerative lesion), grade 1 (partial/fullthickness ulcer), grade 2 (probing to tendon or capsule), grade 3 (deep with osteitis, grade 4 (partial foot gangrene) and grade 5 (whole foot gangrene) $)^{(8)}$.

Wound healing is a highly or chestrated process, which commences with getting rid of debris and combating infection. Inflammation clears the area for angiogenesis to occur to increase blood flow to the wound site. Subsequently, the wound heals through deposition of granulation tissue, wound contraction and maturation. When one of these steps fails, the wound is unable to heal ${ }^{(6,9)}$.

Foot wounds in people with diabetes mellitus have a serious impact on healthrelated quality of life, particularly with respect to physical functioning and role limitations due to physical and emotional issues $^{(10,11)}$. They also represent a major use of health resources, incurring costs not only for dressings, but also staff costs, time tests and investigations, antibiotics and specialist footwear.

The risk of lower limb amputation is much greater for people with diabetes mellitus than for those without. The major underlying pathophysiology associated with amputation is neuropathy and ischemia. Lower limb amputation can have devastating consequences for people's health status and health-related quality of life $^{(12)}$, as well as having a large financial impact on healthcare providers and users. In the UK, from the beginning of April 2007 to 31 March 2010, a total of 16,693 lower limb amputations were recorded in people with diabetes mellitus ${ }^{(13)}$. Of these 10,216 were classed as minor amputations (usually defined as below the ankle joint), and 6,477 as major amputations (usually defined as above the ankle joint). The UK cost of 'foot procedures related to diabetes or arterial disease and procedures to amputation stumps' was estimated at approximately GBP 17 million over 2009/10. In the US, the 2008 prevalence of lower extremity amputation in Medicare recipients was $1.8 \%$, with a total mean annual Medicare reimbursement cost for each person with diabetes mellitus and a lower extremity amputation estimated at USD 54,000. Ulcers are often considered to be chronic wounds, whilst post-surgical amputation sites are considered to be acute wounds, unless they do not heal ${ }^{(14)}$. 
Standard wound management consists of initial surgical debridement, which is a rapid and effective technique to remove devitalized tissue, then dry or moist gauze dressings can be used to cover the wound, ${ }^{(6)}$ which need to be changed frequently. These dressings are relatively inexpensive, readily available and easy to apply. However, there have some disadvantages: non-selective debridement with dressing removal and possible wound desiccation ${ }^{(15)}$.

Amputation debridement is regarded as an important component of the treatment of 'chronic' foot wounds, such as ulcers or non-healing surgical wounds. It can sometimes be undertaken as a surgical procedure. Debridement involves removal of dead tissue and callus along with pressure-relief/off-loading as well as treatment of infection and revascularization, where necessary. As in other areas of wound care, sharp surgical debridement of diabetic foot wounds is recommended in order to promote wound healing by 'converting' a chronic wound to an acute wound via removal of dead tissue and slough $^{(16)}$. While this practice is common, there is little evidence that surgical debridement promotes healing of diabetic foot wounds ${ }^{(17,18)}$, but debridement of necrotic tissue with eschar from wounds, can sometimes be a priority to the use of wound treatments such as negative pressure wound therapy (NPWT).

The nurse plays an important role in wound healing and the total care of the patient, coordinating activities with other disciplines such as occupational and physical therapy. So, optimal care of the WOUND requires a distinctive multidisciplinary approach. Positive patient outcomes are dependent on the composition of the wound care team and close collaboration among its members. At the center of this team is the nurse, the coordinator of all patient care activities. At the same time, the nurse is also a specialist in wound care. As a wound heals, either spontaneously or through excision and grafting, the nurse is responsible for wound care and for noting changes that require immediate attention, prevention of infection and pain management ${ }^{(19)}$.

The key for successful wound care depend on nurses who should have the critical skills as well as the abilities to plan strategies for patient care staring with patient assessment on admission to patient to discharge plan. The nurse is considered the corner stone for promotion of wound healing through assessing the patient conditions, planning patients care, and providing efficient care for respiratory and circulatory systems maintaining mobility, restoring the patients emotional and physical capacity, providing, wound care and preventing of infection through using the efficient method for wound healing less costly by using vacuum assisted therapy ${ }^{(20,21)}$.

Vacuum assisted closure (VAC) therapy is a noninvasive, closed system that applies negative pressure to wound tissue. The vacuum assisted closure (VAC) therapy was first reported in 1990s It has revolutionized the clinical management of the wounds ${ }^{(22)}$. It acts by removing excess tissue fluid from the extravascular space, which promotes microcirculation during the early stages of inflammation. Vacuum therapy induces increased peripheral blood flow and improves local oxygenation ${ }^{(23)}$. It promotes angiogenesis, endothelial proliferation, the integrity of the capillary basement membrane, and stimulates granulation tissue, decreasing interstitial edema and bacterial colonization ${ }^{(24)}$.

The technique of vacuum therapy is very simple; a piece of foam with an open cell structure is introduced into the wound and a wound drain with lateral perforation is laid on top of it then, the entire area is then covered with a transparent adhesive membrane, which is firmly secured to the healthy skin around the wound margins. When exposed end of the drain tube is connected to a vacuum source, fluid is drawn from the wound through the foam 
into a reservoir for subsequent disposal. The plastic membrane prevents the ingress of air and allows a partial vacuum to form within the wound, reducing its volume and facilitating the removal of fluid, the foam ensures that the entire surface area of the wound is uniformly exposed to this negative effect, prevents occlusion of the perforations in the drain by contact with the base or edges of the wound and eliminates the possibility of localized areas of high pressure and resultant tissue necrosis ${ }^{(25)}$.

Vacuum assisted closure (VAC) therapy is used as treatment used to promote healing in acute and chronic wounds by applying negative pressure to the wound bed. These NPWT devices work through application of a disposable, open-cell antimicrobial gauze dressing with a non adherent contact layer or foam dressing to the wound base, which is covered with a semi permeable film drape or transparent adhesive film dressing. An evacuation tube embedded in the dressing is connected through an adjustable vacuum pump to remove effluent to a remote collection container. Microprocessor controls can be programmed or varying pressures and cycles of constant and intermittent suction. The application of sub atmospheric pressure to the dressing results in multiple benefits including: increased local blood flow via enhancement of capillary blood flow increased angiogenesis with profuse granulation formation, increased number of active fibro blasts and macrophage, enhanced epithelial cell migration; decreased bio burden at the same time, the nurse is also a specialist in wound care. As a wound heals, either spontaneously or through excision and grafting, the nurse is responsible for wound care and for noting subtle changes that require immediate attention, prevention of infection and pain managements, bacterial toxins, and subsequent, cessation/delay of healing and decreased tensile strength of the wound, as well as decreased harmful, chronic wound fluid and by - products and subsequent senescent cells and tissue damage ${ }^{(26)}$.
Finally, uses of Vacuum assisted closure (VAC) therapy system reduce cost, time consumed and promotes wound healing by delayed primary or secondary intention through creating a moist wound environment, preparing the wound bed for closure, reducing edema, and promoting formation and perfusion of granulation tissue $^{(27)}$.

\section{Aim of the Study}

The aim of the study was to determine the effect of vacuum assisted closure dressing technique versus conventional dressing on diabetic foot wound healing on diabetic foot wound healing.

\section{Research Hypothesis:}

Diabetic foot wound managed by the VAC technique will demonstrate faster healing lesser infection rates as well as wound healing compared to who managed conventionally therapy.

\section{Materials and Method}

\section{Materials}

Design: A quasi experimental research design was utilized in this study.

Setting: The study was conducted at the Foot Ulcer Care Unite the Main University and Royal Vascular Center Alexandria.

Subjects: A convenience sample of 40 diabetic patients were included in the study, they were divided into two equal groups: study and control group 20 patients in each group:

Study group (I): the study group exposed to vacuum assisted closure dressing technique by the researcher.

Control group (II): the control group exposed to hospital conventional dressing technique Inclusion criteria for the diabetic patients were as follows ${ }^{(6,9)}$ :

\section{Adult 21-60 year.}


2. Patients able to communicate.

3. The patient has either 2nd 3rd, 4th degree diabetic foot wound infection.

4. Patients were selected according to certain wound ulcer criteria; (superficial, involving only the epidermis, the skin appears dry and erthematous without blister and sensitive to air) which are considered as characteristics of grade II, III, IV foot ulcer ${ }^{(6)}$.

5. The patients free from any associating feet deformities: by checking feet for presence of hallux valgus, hammer toes.

6. The patient body mass index were calculated by measuring patients height and body weight then use the equation; $\mathrm{BMI}^{(29)}$.

7. Under-weight patients; Less than 20$24 \mathrm{Kg}$ is considered below ideal body weight and excluded from the study, this is indicated for nutritional status so that will delay healing $\operatorname{process}^{(6,9)}$.

Tools: Two tools were used for this study purpose:

Tool I: Diabetic Foot Wound Ulcer Assessment Structure Interview Schedule

This tool was developed by researcher after reviewing of related literature to assess the diabetic wound area ${ }^{(28)}$. It comprised two parts:

\section{First Part:}

Biosocio-demographic data for patient which included information's related to age, sex, occupation, marital status and education. Clinical data included onset of ulcer, ulcer site, grade of obesity using BMI (patients weight (in kg) Grade (0) BMI 20 $24.9 \mathrm{Kgm} / \mathrm{m} 2=$ desirable weight, Grade (1) BMI 25-29.9 Kgm/ m2=over weight, Grade (2) BMI 30-39.9 Kgm/m2=obese, Grade (3) BMI 40 and over $\mathrm{Kgm} / \mathrm{m} 2=$ morbid obesity and patients height (in meters), lab investigations (serum fasting blood glucose level, post prandial blood glucose level, complete differential blood count (CBC), date of admission, vital signs, type of diabetes and medication used ${ }^{(29)}$.

\section{Second Part:}

This part included Foot and wound assessment: to identify initial foot and wound assessment.

\section{It included two sections namely:}

\section{A- Data related to Foot:}

These data comprised:

1- Foot Sensation; these items were assessed according to the following categories: Sensitive to touch, pain, skin temperature: (hot, cold) and manipulation.

2- Pulsation: pulse in dorsalis pedis (DPP), posterior tibial (PTP).

3- Callus color (red, pink, brown, pale).

4- Formation of callus (thick, skin).

5- Presence of dryness.

6- Presence of fissure.

7- Presence of deformities such as hallux valgus, hammer toes.

\section{B- Wound assessment:}

These sections included;

\section{1- Number of ulcers.}

2- Site: plantar surface of1st, 2nd, 3rd, 4th, and 5thtoe, and whether Sole or Heel ulcer or both.

3- Size in centimeters using a ruler ${ }^{(28)}$.

4- Depth of wound (floor) this was measured a percentage out of a total (Epithelial tissue covering the surface and granulation tissue; type and amount) ${ }^{(8,28)}$.

- The Wagner wound classification system was one of the first described and has, historically, been widely used, although it is now rarely used in clinical 
practice. This system assesses ulcer depth and the presence of osteomyelitis or gangrene and graded them as: grade 0 (pre- or post-ulcerative lesion), grade 1 (partial/full-thickness ulcer), grade 2 (probing to tendon or capsule), grade 3 (deep with osteitis, grade 4 (partial foot gangrene) and grade 5 (whole foot gangrene)(8).

\section{5- Surrounding area necrotic tissues} (Margin); these areas were examined for absence or presence of the following: tenderness, redness, hotness, swelling.

\section{Tool II: Wound Healing Assessment Observational Checklist}

This tool was developed by the researcher after reviewing of related literature to evaluate the effect of dressing techniques on the healing process of diabetic foot wound within 4week; which means every week check healing process by Wound healing observation check list, it included 4 parts: (28)

First Part: Wound healing observation check list:

It contained the following items:

- Complete healing formations which is indicated by presence of healthy granulation tissue covered by migration and proliferation of epithelial cells within the wound space and formation of scar tissue

- Partial healing formation which is indicated by presence of healthy granulation tissue within the wound space or decrease of wound size without formation of scar tissue.

- Incomplete healing: which are detected by absence of improvement in wound characteristic, no scar tissue formation s or unhealthy granulation tissue.

Second Part: Abnormal findings of the diabetic wound healing assessment.

The wound was assessed in relation to the following criteria:
1- Clinical signs of wound infection: redness, hotness, painful sensation, unhealthy cells, tenderness, edema, and maceration, change color of the wound exudates or discharge. Types of exudates "Bloody: thin bright red; Serosanguineous: thin watery, pale red to pink, Serous: thin, watery, clear. Purulent: thin or thick opaque to yellow, Foul purulent: thick, opaque yellow to green". Amount of exudates "Scanty, Small, Moderate and Large" color, Odor "absent, present".

2- Moist granulation tissues.

3- Increased of surface area measurements.

4- Absence of healing epithelial edges.

Third Part: Wound culture (Swab):

Swab culture was performed to patient in the study group and control group (2 groups), whenever signs and symptoms of infection occur.

Fourth Part: Photographic pictures:

Photographic pictures were taken to compare wound healing process before and after dressing for both groups in order to determine diabetic wound healing progress.

\section{Method}

1. Permission to carry out the study was obtained from the directors of the study settings (Diabetic Unit and Vascular Unit) and Royal vascular center after explaining the aim of the study.

2. The tools were developed after reviewing related literature

3 . The tools were tested for content validity by five experts in the field of Medical-surgical Nursing and vascular surgery specialists. The needed modifications were introduced.

4. Reliability of the tool (1) and tool (2) were tested using test retest method for fifty patients.

5. Written patients consent for participation in the study was obtained after informing the patients about the purpose of the study. 
6. A pilot study was carried out on 5 patients in Diabetic Unit to test applicability \& feasibility of the developed tool.

7. Patients were assigned to either to the study group or the control group according to inclusive criteria. The first 20 patients were assigned to the study group whereas the other 20 patients were assigned to the control group. Matches of patients in both groups were done related to biosocial demographic characteristics such as age, sex, and ulcer size and body mass index (BMI).

8. At initial assessment of patients condition were done for both groups using Tool I:

- First part: This assessment was concerned with biosocial demographic characteristics.

- Body mass index was calculated by measuring each patients height and body weight then using the equation; $\mathrm{BMI}=$ weight $/$ height $=\mathrm{Kg} / \mathrm{m}^{2}$ this calculation was done to determine the grade of obesity $^{(30)}$.

- Diabetic wound Assessment: This assessment was carried out using Tool I- second part which included:

\section{A- Identifying the diabetic wound site:}

Wound site was identified by dividing the foot into dorsum, plantar of toes, plantar of metatarsal heads, sole, heel, medial and lateral aspect of foot.

\section{B- Measuring wound size in centimeter:}

These measurements were carried out following as follow as:

\section{Steps:}

- Using standard precautions perform hand hygiene, put on sterile gloves.
- Moist a sterile flexible applicator with saline

- Mark the point on the swab applicator with surrounding skin then grasp the applicator with thumb and forefinger at the point corresponding to the wound margin. Remove the swab applicator and measure the size with ruler.

\section{C- Assessing the surrounding area of the diabetic wound for:}

Signs of inflammation as redness hotness, tenderness and swelling, skin condition as moist or dry.

\section{D- Measure the depth of the foot ulcer:}

The researcher observing the depth, or thickness if the ulcer is superficial (epidermis) or partial thickness or skin loss that involve epidermis and /or dermis by using sterile cotton swab applicator inserted into the deepest point of the wound and marking it at the skin surface level then the swab applicator is measured by using ruler.

\section{E- Assessing Floor of diabetic wound:}

The presence of granulation tissue or necrotic tissue or exposure to tendon was recorded $^{(32,33)}$.

\section{F- Assessment of abnormal findings} of wound healing:

- Clinical signs of wound infection these signs included: as redness, hotness, painful sensation unhealthy cells, tenderness, swelling, maceration, cellulites, edema, and eczema).

- Foot ulcer exudates (type, amount and odor).

- Assessment of neurovascular condition included $^{(34)}$ :

a- Neuro Sensation: Assess feet sensation to touch, pain and manipulation: 
- Assess sensation to touch by asking the patient to close his eyes and the researcher touch the dorsal and plantar surface of the patients feet by the palm, then the patients was asked about the article that touching his feet to know his feet sensation.

- Assess sensation to pain by asking the patient to close his eyes and the researcher used blunt point object such as metal object which moved on planter and dorsal surface of the patients feet then the patient was asked to express his feeling for pain or no feeling of pain.

- Assess sensation to manipulation by asking the patient to close his eyes and manipulate his/her big toe away from the second toe upward and downward position, the patient is asked to point in what direction was the toe moved, if his answers immediately, so his sense for position is intact, but if he hesitated or do not know the direction of the toe, so his sense to manipulation considered absent.

\section{b- Assess circulation of patient's feet:}

Palpating the pulse at dorsal is pedis and posterior tibial arteries.

\section{c- Assess the temperature of patient's feet $^{(35)}$ :}

Palpating using palm of the hand temperature of the involved patient's feet was assessed with other feet to reflect the efficiency of arterial circulation. Also, the patient was asked about his feet temperature during hot weather (worm or cold). d- Assess any abnormalities in the patient's feet: This assessment was done through observation of the condition of the skin for normal skin, dry or moist, for presence of callus (thick skin), and colure, (red, pink, brown or pale) as well as presence of dryness.

9. Assessment of wound area was done using Tool I -second part and by photo graphic at the initial meeting using Tool II- fourth part.

10. Dressings were done by the researcher for both groups as follows: (Appendix III).

- The study group: The patients in the study group were managed by VAC at dressing room using the following steps:

1. Wash hands with soap and water and dries it well then wears the sterile gloves to prevent cross infection.

2. Clean the wound are with normal saline using antiseptic technique.

3. Debridement of the wound was done by removing dry skin around the wound area; dead tissue was removed by scalpel and forceps till floor of wound bleeds.

4. Washing the wound area by normal saline $0.9 \%$.

5. Clean the area around the wound with normal saline solution $0.9 \%$.

6. Dry the wound.

7. Study group subjects were dressed by VAC therapy dressing technique once daily till healing occurs or discharge of patients ( 2 week or 4 week-). A sterile open cell sponge is placed in the wound, a tube is passed through it then sealed with an adherent film, and sub atmospheric pressure is applied by suction machine or 
Redivac. This dressing was changed every 3 days.

Wound swab cultures for microorganisms were obtained before dressing and weekly there after till the end of VAC therapy.

The control group: patients in the control group were exposed to the hospital conventional dressing technique which included: the same previous steps but applying (povidoniodin) solution on the wound then covering the area with gauze to help hold the gauze in the place and to absorb drainage ${ }^{(31)}$.

Steps followed by the researcher before performing the dressing for both groups:

A-preparation of the environment:

Maintain clean hygiene environment in dressing room.

Keep windows and doors at the dressing room closed to prevent air drafts.

\section{B- Preparation of the equipment:}

Equipment were prepared for the two dressing techniques included disposable mask, disposable gloves, plastic bag, tap measure, camera, scissor, artery forceps, antiseptic solutions, scalpel blade, cotton sponge gauze, dressing and Elastoplast bandage.

\section{C- Preparation of patients:}

- Explain the procedure to the patient.

- Place the patient in a comfortable position.

- Place a water resistant pad under the leg.

- Set up disposable plastic bag in a suitable location to the wound.

Steps followed at the end of dressing:
- Clean all used equipment used.

- Supplies are wasted.

- Wash hands to prevent cross infection (while the patients still in hospital).

\section{Evaluation:}

\section{Frequency of evaluation:}

\section{Wound culture:}

According to the steps as following: (for both groups):

- Wash hands with soap and water and dry well then wear the gloves before culture procedures to prevent cross infection.

- Expose the wound area.

- Using the cotton - tipped applicator swab and collect as much exudates as possible from the center of the lesion.

- Place the swab immediately in the appropriate tube, transport culture tube and send to laboratory, labeled clearly with name of patient, date room number, bed number specifying anatomic part from where the specimen was obtained.

- Record any abnormality if occurred.

11. Calculate the frequency of wound healing and performance of dressing in each dressing technique which performed once daily until healing occur.

12. Collection of data was done through a period of 10 months from the beginning of March 2014 to end of December 2014.

\section{Ethical considerations:}

Confidentiality and privacy of patient's data were asserted. Participation in the study was voluntary, with the patient right to withdraw at any time. 


\section{Statistical Analysis}

Data were fed to the computer and analyzed using IBM SPSS software package version 20.0. Qualitative data were described using number and percent. Quantitative data were described using range (minimum and maximum), means and, standard deviations. Comparisons between groups for categorical variables were assessed using Chi-square test and Fisher's Exact or Monte Carlo correction. Significance of the obtained results was judged at the $5 \%$ level $^{(36)}$.

\section{Results}

Table (1) illustrated that of patients according to their socio demographic variables. For group II it was $12(60 \%)$ were male and females were $8(40 \%)$ while in group I there males were $15(75 \%)$ and females were 5 (25\%).

Age from 18-25 in conventional group was $12(60 \%)$ and from $26-35$ was $8(40 \%)$. In VAC therapy, age from $18-25$, and from 26-35 was the same 10 (50\%).

Regarding education, half of the patients were illiterate $10(50 \%)$ in conventional group II and 9 (45\%) read \& write in group I. Regarding, the most frequent number was manual workers $14(70 \%), 16(80 \%)$ in both group respectively.

Table (2) shows distribution of patients of both group study and control according to Type of diabetes, treatment received and body mass index. Type of diabetes NIDDM was higher in both study groups control $17(85 \%), 16(80 \%)$ respectively, treatment with hypoglycemic agents was higher in both study groups 14(70\%), 15 (75\%) respectively.

Normal body mass index was higher in both study groups $11(55 \%), 12(60 \%)$ study and control groups respectively. There was no statistical significant difference regarding to type of diabetes, treatment and body mass index $(\mathrm{P}>0.05)$.
Table (3) shows comparison between the two studied groups according to wound assessment. Regarding site of ulcer, heel was higher in conventional occlusive dressing group 7(35\%) and in VAC therapy dressing group, plantar surface $1^{\text {st }}$ metatarsal head 5(33.3\%) was higher. There was statistical significant difference between the two studied groups according to site of ulcer $(\mathrm{P}<0.5)$.

Size of ulcer was $2-4 \mathrm{~cm}$ was $10(50 \%)$ and $11(55 \%)$ in both group control and study respectively and size > 4-6 cm was $10(50 \%)$ and $9(45 \%)$ in both group respectively. Grade III, IV was higher in both group $7(35 \%), 6(30 \%)$ and $7(35 \%)$, $7(35 \%)$ respectively.

Regarding color of callus, read pink was higher in both group control and study $7(35 \%), 8(40 \%)$ respectively and present dryness was higher in both groups control and study 17(85\%), 16(80\%) respectively. Present fissure was higher in both groups with the same number $16(80 \%)$.

There was no statistical significant difference between the two studied groups according to size of ulcer, depth of ulcer, color of callus, dryness and fissure $(\mathrm{P}>0.05)$.

Table (4) shows percentage distribution of patients of both group control and study according to bacterial wound culture according to bacteriological culture results before dressing, positive cases was higher in conventional groups $12(60 \%)$, respectively. while in VAC group lower. There was statistical significant difference between two studied groups and bacterial wound culture $(\mathrm{P}>0.05)$.

Table (5) shows Percentage distribution of patients of both group according to wound morphology and sign of infection at 3 different intervals (1-3 weeks) according to wound morphology and sign of infection per weeks. There was no statistical significant difference between the conventional occlusive dressing and VAC gloves groups of diabetic foot ulcer 
according to wound morphology and sign of infection per weeks $(\mathrm{P}>0.05)$.

Table (6) shows distribution of patients of both groups according to wound healing during hospital stay period. There was statistical significant difference regarding wound healing after second week, after third week and before discharge $(\mathrm{P}<0.05)$.

Table (7) shows mean and standard deviation according to, cost of dressing and time consumed until complete healing. Cost of dressing in conventional group ranged 437.00-969.00 with mean value $715.65 \pm 166.93$ and in VAC group ranged 338.00-699.50 with mean value 508.93 \pm 130.59 . Time consumed in conventional group ranged 76.0-120.0 with mean value $94.07 \pm 6.20$ and in VAC group ranged 19.0-55.0 with mean value 42.49 \pm 7.68 .

\section{Discussion}

The role of negative pressure dressing (VAC) in healing of diabetic foot ulcers has been proposed as a novel method of manipulating the chronic wound environment in a way that it reduces bacterial burden and chronic interstitial wound fluid, increases vascularity and cytokine expression and to an extent mechanically exploiting the viscoelasticity of per wound tissues ${ }^{(37)}$. VAC is generally well-tolerated and, with few contraindications or complications, is fast becoming a mainstay of current wound care. Hence study aim to determine the effect of vacuum assisted closure dressing technique versus conventional dressing on diabetic foot wound healing on diabetic foot wound healing.

The demographical profile was statistically studied and found with no significant difference between the two groups. The mean age of patients in study group was the same the study findings done by and which was comparable to the multicenter randomized controlled trial enrolling 342 patients done by Blume et al.
$(2005)^{(38)}$ who had a mean age of 58 years. The sex distribution was also similar to the above quoted study that had $75 \%$ males.

The result revealed that there was a decreasing trend in the presence of wound discharge in both the groups. However, it was noted that the rate of disappearance of wound discharge was faster in the study group as compared to the control. Only less than half of patients in study group had discharge after third week as compared to zero\% of patients in control group. This could be attributed to the faster rate of wound closure in the study group. In a similar study conducted by Tamhankar et al. $(2009)^{(39)}$ in patients which were treated by VAC therapy, it was seen that VAC therapy allows salvage of infected exposed mesh by clearing the purulent discharge promoting granulation tissue formation.

Application of negative pressure over wound bed allows the arterioles to dilate, so increasing the effectiveness of local circulation, promoting angiogenesis, which assists in the proliferation of granulation tissue $^{(40)}$. Also found that the patients on VAC therapy had earlier appearance of granulation tissue. Of all the patients who initially did not have granulation tissue, half of those in the study group promised its appearance by the end of 2 nd week as compared to minority of the control group and this was also found to be statistically significant $\quad(\mathrm{P}<0.05)$. Shrestha et al. $(2007)^{(41)}$ found in their prospective study of nine patients of renal transplantation wound infections following Renal Therapy, progressive reduction in the size of wound and development of healthy granulation tissue in all the cases.

Furthermore there were a statistically significant difference in the percentage change in the wound size between both the groups $(\mathrm{P}<0.05)$. The mean decrease in the wound size was more in the study groups compared to the control group. Current study is consistent with McCallon et al. $(2000)^{(42)}$ who had observed average decrease in wound size in the VAC group as 
compared to average increase in wound size in control group. Mark Eginton et al. $(2003)^{(43)}$ had also observed that the wound volume and depth decreased significantly in VAC dressings as compared to moist gauze dressings $59 \%$ vs. $0 \%$ and $49 \%$ vs. $8 \%$, respectively.

On the other hand the result indicated that patients of study group showed rapid clearance of bacterial load as compared to control group. This was suggested less than half of the cultures in study group having no growth by $3^{\text {rd }}$ week as compared to $20 \%$ in control group. The decrease in the bacterial load could have been attributed to the antibiotic regimes administered during the study. Hence we were unable to eliminate this bias. However, S. aureus was found to be most prominent in the study group whereas cultures from control group mostly showed mixed growth and Acinetobacter. Correlates with the study by Moues et al. $(2004)^{(44)}$ observed that non fermentative Gram-negative bacilli showed a significant decrease in vacuum-assisted closure-treated wounds, whereas S. aureus showed a significant increase in VAC-treated wounds.

Although statistically the time of wound closure was comparable in both the groups $(\mathrm{P}>0.10)$, it was seen that the study group showed faster rate of wound closure as compared to control group. McCallon et al. $(2000)^{(42)}$ also observed satisfactory healing in VAC group in $22.8 \pm 17.4$ days, compared to $42.8 \pm 32.5$ days in control group.

The endpoint taken was a granulated wound or a wound ready for skin grafting or healing by secondary intention spontaneously whichever was earlier. Both the groups had received similar treatment for the closure of wound, the most common mode of wound closure being. It was also observed that the failure rate was higher in patients of control group as compared to study group. Current study correlates with the study conducted by David Armstrong et al. $(2005)^{(37)}$ they had observed that NPWT delivered by VAC device was safe and effective treatment for complex diabetic foot wounds and could lead to higher proportion of healed wounds, faster healing rates and potentially fewer re-amputations than standard care. Similarly, Robert Frykberg et al. (2007) ${ }^{(45)}$ have also reported overall progressively increasing wound debridement depth, amputation rates in control groups; however the same increasing trend did not occur in the NPWT group.

At the end of the study, the study group promised a better outcome as compared to the control group (60\% complete responders).

Analyzing the study result concluded that $\mathrm{VAC}$ has a definitive role in promotion of proliferation of granulation tissue, reduction in the wound $\operatorname{size}^{(46)}$, rapid clearing of the wound discharge and bacterial load. Current data demonstrates that negative pressure wound dressings decrease the wound size more effectively than Iodine gauze dressings over the first 4 weeks of therapy.

\section{Conclusion}

In the light of the study findings it can concluded that using of VAC therapy yield improved wound healing in comparison to their control in patient with diabetes mellitus more over the majority of studied patients who had faster and more effective wound healing (healing time, cost effectively, reduction time surface skin healing).

\section{Recommendations}

- In service education program should be carried out for nurses regarding to:

- Using VAC therapy technique.

- Wound dressing. 
Table (1): Distribution of patients according to their sociodemographic variables

\begin{tabular}{|c|c|c|c|c|}
\hline \multirow[t]{2}{*}{ Variables } & \multicolumn{2}{|c|}{$\begin{array}{c}\text { Group I } \\
\text { (study group_ } \\
\text { VAC therapy } \\
\text { dressing) } \\
(\mathbf{n}=\mathbf{2 0}) \\
\end{array}$} & \multicolumn{2}{|c|}{$\begin{array}{c}\text { Group II } \\
\text { (control group_- } \\
\text { Conventional } \\
\text { occlusive dressing) } \\
(\mathbf{n}=\mathbf{2 0})\end{array}$} \\
\hline & No. & No. & No. & $\%$ \\
\hline $\begin{array}{l}\text { Sex } \\
\text { Male } \\
\text { Female }\end{array}$ & $\begin{array}{c}15 \\
5\end{array}$ & $\begin{array}{l}75.0 \\
25.0\end{array}$ & $\begin{array}{c}12 \\
8\end{array}$ & $\begin{array}{l}60.0 \\
40.0\end{array}$ \\
\hline Total & 20 & 100.0 & 20 & 100.0 \\
\hline $\begin{array}{l}\text { Age } \\
18-25 \\
26-35\end{array}$ & $\begin{array}{l}10 \\
10\end{array}$ & $\begin{array}{l}50.0 \\
50.0\end{array}$ & $\begin{array}{c}12 \\
8\end{array}$ & $\begin{array}{l}60.0 \\
40.0\end{array}$ \\
\hline Total & 20 & 100.0 & 20 & 100.0 \\
\hline $\begin{array}{l}\text { Education } \\
\text { Illiterate } \\
\text { Read \& Write } \\
\text { Diploma } \\
\text { Bachelor degree } \\
\end{array}$ & $\begin{array}{l}6 \\
9 \\
5 \\
0 \\
\end{array}$ & $\begin{array}{c}30.0 \\
45.0 \\
25.0 \\
0.0 \\
\end{array}$ & $\begin{array}{c}10 \\
5 \\
5 \\
0 \\
\end{array}$ & $\begin{array}{c}50.0 \\
25.0 \\
25.0 \\
0.0 \\
\end{array}$ \\
\hline Total & 20 & 100.0 & 20 & 100.0 \\
\hline $\begin{array}{l}\text { Occupation } \\
\text { Manual } \\
\text { Clerical } \\
\text { No work }\end{array}$ & $\begin{array}{c}16 \\
0 \\
4 \\
\end{array}$ & $\begin{array}{c}80.0 \\
0.0 \\
20.0 \\
\end{array}$ & $\begin{array}{c}14 \\
0 \\
6 \\
\end{array}$ & $\begin{array}{c}70.0 \\
0.0 \\
30.0\end{array}$ \\
\hline Total & 20 & 100.0 & 20 & 100.0 \\
\hline
\end{tabular}


Table (2): Distribution of patients of both group study and control according to type of diabetes, treatment received and body mass index

\begin{tabular}{|c|c|c|c|c|c|c|}
\hline \multirow[t]{2}{*}{ Items } & \multicolumn{2}{|c|}{$\begin{array}{c}\text { Group I } \\
\text { (study group_- } \\
\text { VAC therapy } \\
\text { dressing) } \\
(n=20)\end{array}$} & \multicolumn{2}{|c|}{$\begin{array}{c}\text { Group II } \\
\text { (control group_ } \\
\text { Conventional } \\
\text { occlusive dressing) } \\
(\mathbf{n}=\mathbf{2 0})\end{array}$} & \multirow[t]{2}{*}{$x^{2}$} & \multirow[t]{2}{*}{$\mathbf{p}$} \\
\hline & No. & $\%$ & No. & $\%$ & & \\
\hline $\begin{array}{l}\text { Type of diabetes } \\
\text { IDDM } \\
\text { NIDDM }\end{array}$ & $\begin{array}{c}4 \\
16\end{array}$ & $\begin{array}{l}20.0 \\
80.0\end{array}$ & $\begin{array}{c}3 \\
17\end{array}$ & $\begin{array}{l}15.0 \\
85.0\end{array}$ & 0.173 & ${ }^{F E} \mathrm{p}=1.000$ \\
\hline $\begin{array}{l}\text { Treatment } \\
\text { Insulin } \\
\text { Hypoglycaemic agents }\end{array}$ & $\begin{array}{c}5 \\
15\end{array}$ & $\begin{array}{l}25.0 \\
75.0\end{array}$ & $\begin{array}{c}6 \\
14 \\
\end{array}$ & $\begin{array}{l}30.0 \\
70.0\end{array}$ & 0.125 & 0.723 \\
\hline $\begin{array}{l}\text { Body mass index } \\
\text { Normal }(18.5-24.9) \\
\text { Overweight }(\uparrow 14.9) \\
\text { Underweight }(\downarrow 18.5)\end{array}$ & $\begin{array}{c}12 \\
8 \\
0 \\
\end{array}$ & $\begin{array}{c}60.0 \\
40.0 \\
0.0 \\
\end{array}$ & $\begin{array}{c}11 \\
9 \\
0 \\
\end{array}$ & $\begin{array}{c}55.0 \\
45.0 \\
0.0 \\
\end{array}$ & 0.102 & 0.749 \\
\hline Total & 20 & 100.0 & 20 & 100.0 & & \\
\hline
\end{tabular}

$\chi^{2}$ : value for Chi square test

FE: Fisher Exact test 
Table (3): Comparison between the two studied groups according to wound assessment

\begin{tabular}{|c|c|c|c|c|}
\hline \multirow[t]{2}{*}{ Wound assessment } & \multicolumn{2}{|c|}{$\begin{array}{c}\text { Group I } \\
\text { VAC therapy dressing } \\
(\mathbf{n}=20)\end{array}$} & \multicolumn{2}{|c|}{$\begin{array}{c}\text { Group II } \\
\text { Conventional occlusive } \\
\text { dressing } \\
(\mathbf{n}=\mathbf{2 0})\end{array}$} \\
\hline & No. & $\%$ & & \\
\hline $\begin{array}{l}\text { Site of wound } \\
\text { Plantar surface } 1^{\text {st }} \text { toe }\end{array}$ & 1 & 6.7 & 3 & 15.0 \\
\hline Plantar surface $1^{\text {st }}$ metatarsal & 5 & 333 & 3 & 150 \\
\hline $\begin{array}{l}\text { head } \\
\text { Plantar surface } 2^{\text {nd }} \text { toe }\end{array}$ & 0 & 0.0 & 3 & 150 \\
\hline Plantar surface $4^{\text {th }}$ toe & 2 & $\begin{array}{c}0.0 \\
13.3\end{array}$ & $\begin{array}{l}3 \\
0\end{array}$ & $\begin{array}{c}15.0 \\
0.0\end{array}$ \\
\hline Plantar surface $5^{\text {th }}$ toe & 4 & 26.7 & 0 & 0.0 \\
\hline Sole & 1 & 6.7 & 4 & 20.0 \\
\hline Heel & 2 & 13.3 & 7 & 35.0 \\
\hline$\chi^{2}\left({ }^{M C} p\right)$ & \multicolumn{4}{|c|}{$13.112^{*}\left(0.019^{*}\right)$} \\
\hline \multicolumn{5}{|l|}{ Size of $u$} \\
\hline $2-4 \mathrm{~cm}$ & 11 & 55.0 & 10 & 50.0 \\
\hline$>4-6 \mathrm{~cm}$ & 9 & 45.0 & 10 & 50.0 \\
\hline$\chi^{2}(\mathbf{p})$ & \multicolumn{4}{|c|}{$0.100(0.752)$} \\
\hline Depth of ulcer & & & & \\
\hline Grade I & 0 & 0.0 & 0 & 0.0 \\
\hline Grade II & 3 & 15.0 & 4 & 20.0 \\
\hline Grade III & 6 & 30.0 & 7 & 35.0 \\
\hline Grade IV & 7 & 35.0 & 7 & 35.0 \\
\hline Grade V & 4 & 20.0 & 2 & 10.0 \\
\hline$\chi^{2}\left({ }^{M C} p\right)$ & \multicolumn{4}{|c|}{$0.987(0.887)$} \\
\hline Color of callus & & & & \\
\hline Red & 4 & 20.0 & & \\
\hline Pink & 8 & 40.0 & & \\
\hline Brown & 3 & 15.0 & & \\
\hline Pale & 5 & 25.0 & & \\
\hline$\chi^{2}\left({ }^{M C} p\right)$ & \multicolumn{4}{|c|}{$0.371(1.000)$} \\
\hline Dryness & & & & \\
\hline Present & 16 & 80.0 & 17 & 85.0 \\
\hline Absent & 4 & 20.0 & 3 & 15.0 \\
\hline$\chi^{2}\left({ }^{\mathrm{FE}} p\right)$ & \multicolumn{4}{|c|}{$0.173(1.000)$} \\
\hline Fissure & & & & \\
\hline Present & 16 & 80.0 & 16 & 80.0 \\
\hline Absent & 4 & 20.0 & 4 & 20.0 \\
\hline$\chi^{2}\left({ }^{\mathrm{FE}} \mathbf{p}\right)$ & \multicolumn{4}{|c|}{$0.0(1.000)$} \\
\hline
\end{tabular}

$\chi^{2}$ : value for Chi square test 
Table (4): Percentage distribution of patients of both group control and study according to bacterial wound culture

\begin{tabular}{|c|c|c|c|c|}
\hline \multirow[t]{2}{*}{ Bacterial wound culture } & \multicolumn{2}{|c|}{$\begin{array}{c}\text { Group I } \\
\text { VAC therapy dressing } \\
\text { (Study) } \\
(\mathbf{n}=\mathbf{2 0}) \\
\end{array}$} & \multicolumn{2}{|c|}{$\begin{array}{c}\text { Group II } \\
\text { Conventional occlusive } \\
\text { dressing (Control) } \\
(\mathbf{n}=\mathbf{2 0}) \\
\end{array}$} \\
\hline & No. & $\%$ & No. & $\%$ \\
\hline $\begin{array}{l}\mathbf{1}^{\text {st }} \text { culture (before dressing) } \\
\text { Positive } \\
\text { Negative }\end{array}$ & $\begin{array}{c}12 \\
8\end{array}$ & $\begin{array}{l}60.0 \\
40.0\end{array}$ & $\begin{array}{c}12 \\
8\end{array}$ & $\begin{array}{l}60.0 \\
40.0\end{array}$ \\
\hline Total & 20 & 100.0 & 20 & 100.0 \\
\hline $\begin{array}{l}\mathbf{1}^{\text {st }} \text { culture (after dressing) } \\
\text { Positive } \\
\text { Negative }\end{array}$ & $\begin{array}{c}0 \\
20\end{array}$ & $\begin{array}{c}0.0 \\
100.0\end{array}$ & $\begin{array}{c}8 \\
12\end{array}$ & $\begin{array}{l}40.0 \\
60.0\end{array}$ \\
\hline Total & 20 & 100.0 & 20 & 100.0 \\
\hline$\chi^{2}(p)$ & \multicolumn{4}{|c|}{$10.0^{*}\left(0.002^{*}\right)$} \\
\hline
\end{tabular}

$\chi^{2}$ : value for Chi square test

*: Statistically significant at $\mathrm{p} \leq 0.05$

Table (5): Percentage distribution of patients of both group according to wound morphology and sign of infection at 3 different intervals (1-3 weeks)

\begin{tabular}{|c|c|c|c|c|c|c|c|c|c|c|c|c|}
\hline \multirow{3}{*}{ Items } & \multicolumn{4}{|c|}{ 1 $^{\text {st }}$ week } & \multicolumn{4}{|c|}{$2^{\text {nd }}$ week } & \multicolumn{4}{|c|}{$3^{\text {rd }}$ week } \\
\hline & \multicolumn{2}{|c|}{$\begin{array}{c}\text { Group I } \\
\text { VAC } \\
\text { therapy } \\
\text { dressing } \\
(\mathrm{n}=\mathbf{2 0})\end{array}$} & \multicolumn{2}{|c|}{$\begin{array}{c}\text { Group II } \\
\text { Conventional } \\
\text { occlusive } \\
\text { dressing } \\
(n=4)\end{array}$} & \multicolumn{2}{|c|}{$\begin{array}{l}\text { Group I } \\
\text { VAC } \\
\text { therapy } \\
\text { dressing } \\
(\mathrm{n}=\mathbf{2 0})\end{array}$} & \multicolumn{2}{|c|}{$\begin{array}{l}\text { Group II } \\
\text { Conventional } \\
\text { occlusive } \\
\text { dressing } \\
(n=4)\end{array}$} & \multicolumn{2}{|c|}{$\begin{array}{l}\text { Group I } \\
\text { VAC } \\
\text { therapy } \\
\text { dressing } \\
(n=20)\end{array}$} & \multicolumn{2}{|c|}{$\begin{array}{c}\text { Group II } \\
\text { Conventional } \\
\text { occlusive } \\
\text { dressing } \\
(n=4)\end{array}$} \\
\hline & No. & $\%$ & No. & $\%$ & No. & $\%$ & No. & $\%$ & No. & $\%$ & No. & $\%$ \\
\hline $\begin{array}{l}\text { Appearance of wound } \\
\text { Granulation } \\
\end{array}$ & 0 & 0.0 & 0 & 0.0 & 11 & 55.0 & 8 & 40.0 & 2 & 100.0 & 4 & 100.0 \\
\hline$\chi^{2}(p)$ & \multicolumn{4}{|c|}{ - } & \multicolumn{4}{|c|}{$1.600(0.206)$} & \multicolumn{4}{|c|}{ - } \\
\hline Re-epithelialization & 12 & 60.0 & 8 & 40.0 & 20 & 100.0 & 17 & 85.0 & 2 & 100.0 & 4 & 100.0 \\
\hline$\chi^{2}(p)$ & \multicolumn{4}{|c|}{$1.758(0.185)$} & \multicolumn{4}{|c|}{$3.243(0.072)$} & \multicolumn{4}{|c|}{-} \\
\hline Sign of infection & & & & & & & & & & & & \\
\hline Tenderness & 3 & 15.0 & 5 & 25.0 & 1 & 5.0 & 2 & 10.0 & 0 & 0.0 & 0 & 0.0 \\
\hline Erythema & 2 & 10.0 & 5 & 25.0 & 1 & 5.0 & 2 & 10.0 & 0 & 0.0 & 0 & 0.0 \\
\hline Purulent exudates & 0 & 0.0 & 0 & 0.0 & 0 & 0.0 & 0 & 0.0 & 0 & 0.0 & 0 & 0.0 \\
\hline $\begin{array}{l}\text { Conversion of } 2^{\text {nd }} \\
\text { degree to } 3\end{array}$ & 0 & 0.0 & 0 & 0.0 & 0 & 0.0 & 0 & 0.0 & 0 & 0.0 & 0 & 0.0 \\
\hline $\begin{array}{l}\text { Brown or black } \\
\text { discoloration }\end{array}$ & 0 & 0.0 & 0 & 0.0 & 0 & 0.0 & 0 & 0.0 & 0 & 0.0 & 0 & 0.0 \\
\hline МСр & \multicolumn{4}{|c|}{1.000} & \multicolumn{4}{|c|}{-} & \multicolumn{4}{|c|}{-} \\
\hline
\end{tabular}


Table (6): Distribution of patients of both groups according to wound healing during hospital stay period

\begin{tabular}{|c|c|c|c|c|c|c|c|c|}
\hline \multirow{2}{*}{$\begin{array}{l}\text { Wound healing during hospital } \\
\text { stay period }\end{array}$} & \multicolumn{2}{|c|}{$\begin{array}{l}\text { After First } \\
\text { week }\end{array}$} & \multicolumn{2}{|c|}{$\begin{array}{c}\begin{array}{c}\text { After Second } \\
\text { week }\end{array} \\
\end{array}$} & \multicolumn{2}{|c|}{$\begin{array}{c}\text { After Third } \\
\text { week }\end{array}$} & \multicolumn{2}{|c|}{$\begin{array}{c}\text { Before } \\
\text { discharge }\end{array}$} \\
\hline & No. & $\%$ & No. & $\%$ & No. & $\%$ & No. & $\%$ \\
\hline $\begin{array}{l}\text { Group I (VAC dressing) } \\
\text { Study group }\end{array}$ & \multicolumn{2}{|c|}{$(\mathrm{n}=\mathbf{2 0})$} & \multicolumn{2}{|c|}{$(\mathbf{n}=\mathbf{2 0})$} & \multicolumn{2}{|c|}{$(\mathrm{n}=15)$} & \multicolumn{2}{|c|}{$(\mathrm{n}=10)$} \\
\hline Complete & 0 & 0 & 0 & 0.0 & 7 & 46.7 & 8 & 80.0 \\
\hline Partial & 0 & 0 & 10 & 50.0 & 6 & 40.0 & 2 & 20.0 \\
\hline No healing & 20 & 100.0 & 10 & 50.0 & 2 & 13.3 & 0 & 0.0 \\
\hline $\begin{array}{l}\text { Group II (Conventional } \\
\text { dressing) }\end{array}$ & \multicolumn{2}{|c|}{$(n=20)$} & \multicolumn{2}{|c|}{$(n=20)$} & \multicolumn{2}{|c|}{$(\mathrm{n}=17)$} & \multicolumn{2}{|c|}{$(n=15)$} \\
\hline Complete & 0 & 0 & 0 & 0.0 & 0 & 0.0 & 4 & 26.7 \\
\hline Partial & 0 & 0 & 3 & 15.0 & 5 & 29.4 & 6 & 40.0 \\
\hline No healing & 20 & 100.0 & 17 & 85.0 & 12 & 70.6 & 5 & 33.3 \\
\hline$\chi^{2}$ & \multicolumn{2}{|r|}{-} & \multicolumn{2}{|c|}{$5.584^{*}$} & \multicolumn{2}{|c|}{$14.602^{*}$} & \multicolumn{2}{|c|}{$7.150^{*}$} \\
\hline${ }^{N} C_{p}$ & \multicolumn{2}{|c|}{ - } & \multicolumn{2}{|c|}{$0.018^{*}$} & \multicolumn{2}{|c|}{$0.001^{*}$} & \multicolumn{2}{|c|}{$0.025^{*}$} \\
\hline
\end{tabular}

$\chi^{2}$ : value for Chi square

MC: Monte Carlo test

*: Statistically significant at $\mathrm{p} \leq 0.05$

\#: The remaining numbers of patients in each type of technique were discharged

Table (7): Mean and standard deviation according to, cost of dressing and time consumed until complete healing

\begin{tabular}{|l|c|c||}
\hline Items & $\begin{array}{c}\text { Group I } \\
\text { VAC therapy dressing } \\
(\mathbf{n = 2 0})\end{array}$ & $\begin{array}{c}\text { Group I } \\
\text { Conventional occlusive } \\
\text { dressing } \\
(\mathbf{n = 2 0})\end{array}$ \\
\hline Cost of dressing & $338.00-699.50$ & $437.00-969.00$ \\
Range & $508.93 \pm 130.59$ & $715.65 \pm 166.93$ \\
Mean \pm SD & & \\
Time consumed & & $76.0-120.0$ \\
(days) & $19.0-55.0$ & $94.07 \pm 6.20$ \\
Range & $42.49 \pm 7.68$ & Mean \pm SD \\
\hline
\end{tabular}




\section{References}

1. Dumville JC, Hinchliffe RJ, Cullum N, Game F, Stubbs N, Sweeting M, et al. Negative pressure wound therapy for treating foot wounds in people with diabetes mellitus. Cochrane Database Syst Rev 2013; 10: CD010318.

2. Singh N, Armstrong DG, Lipsky BA. Preventing foot ulcers in patients with diabetes. JAMA 2005; 293(2): 217-28.

3. Abbott CA, Carrington AL, Ashe H, Bath S, Every LC, Griffiths J, et al. The North West Diabetes Foot Care Study: incidence of and risk factors for new diabetic foot ulceration in a community-based patient cohort. Diabetic Med 2002; 19(5): 37784.

4. Dumville JC, Deshpande S, O'Meara S, Speak K. Hydrocolloid dressings for healing diabetic foot ulcers. Cochrane Database Syst Rev 2013; 8: CD009099.

5. Margolis D, Malay DS, Hoffstad OJ, Leonard CE, MaCurdy T, Lopez de Nava K, et al. Prevalence of diabetes, diabetic foot ulcer, and lower extremity amputation among Medicare beneficiaries, 2006 to 2008. Diabetic foot ulcers. Data Points \#1 (prepared by the University of Pennsylvania DEcIDE Center, under Contract No. HHSA29020050041I). Rockville, MD: Agency for Healthcare Research and Quality; 2011.

6. Bowler PG. Wound pathophysiology, infection and therapeutic options. Ann Med 2002; 34(6): 419-27.

7. Joseph E, Hamori CA, Bergman S, Roaf E, Swann NF, Anastasi GW. A prospective randomized trial of vacuum-assisted closure versus standard therapy of chronic nonhealing wounds. Wounds 2000; 12(3): 60-7.
8. Dumville JC, Deshpande S, O'Meara S, Speak K. Foam dressings for healing diabetic foot ulcers. Cochrane Database Syst Rev 2013; 6: CD009111.

9. McCallon SK, Knight CA, Valiulus JP, Cunningham MW, McCulloch JM, Farinas LP. Vacuum-assisted closure versus saline-moistened gauze in the healing of postoperative diabetic foot wounds. Ostomy Wound Manage 2000; 46(8): 28-32.

10. Nabuurs-Franssen MH, Huijberts MS, Nieuwenhuijzen Kruseman AC, Willems J, Schaper NC. Health-related quality of life of diabetic foot ulcer patients and their caregivers. Diabetologia 2005; 48(9): 1906-10.

11. Ribu L, Hanestad BR, Moum T, Birkeland K, Rustoen T. A comparison of the health-related quality of life in patients with diabetic foot ulcers, with a diabetes group and a non diabetes group from the general population. Qual Life Res 2007; 16(2): 179-89.

12. Tennvall GR, Apelqvist J. Health related quality of life in patients with diabetes mellitus and foot ulcers. J Diabetes Complications 2000; 14(5): 235-41.

13. Holman N, Young RJ, Jeffcoate WJ. Variation in the recorded incidence of amputation of the lower limb in England. Diabetologia 2012; 55(7): 1919-25.

14. Ubbink DT, Westerbos SJ, Nelson EA, Vermeulen H. A systematic review of topical negative pressure therapy for acute and chronic wounds. British J Surg 2008; 95(6): 685-92.

15. Venturi ML, Attinger CE, Mesbahi AN, Hess Cl, Gram KS. Mechanisms and clinical applications of vacuumassisted closure (VAC) devices: a review. Am J Clin Dermatol 2005; 6(3): 185-94. 
16. Steed DL, Attinger C, Colaizzi T, Crossland M, Franz M, Harkless L, et al. Guidelines for the treatment of diabetic ulcers. Wound Repair Regen 2006; 14(6): 680-92.

17. Eneroth M, Van Houtum WH. The value of debridement and VacuumAssisted Closure (V.A.C.) Therapy in diabetic foot ulcers. Diabetes Metab Res Rev 2008; 24(Suppl 1): S76-80.

18. Lebrun E, Tomic-Canic M, Kirsner RS. The role of surgical debridement in healing of diabetic foot ulcers. Wound Repair Regen 2010; 18(5): 433-8.

19. Greenfield E. The pivotal role of nursing personnel in burn care. Indian $\mathbf{J}$ Plastic Surg 2010; 43(Suppl): S94-100.

20. Marquis BL, Huston CJ. Leadership roles and management functions in nursing: theory and application. Philadelphia: Lippincott Williams \& Wilkins; 2009.

21. Knottnerus AJ. The evidence base of clinical diagnosis. London: BMJ Books; 2002.

22. Moues C, Heule F, Legerstee R. Topical Negative Pressure in Wound Care Effectiveness and guidelines for clinical application. OstomyWound Manage 2009; 55: 16-32.

23. Trop M, Schintler M, Urban E, Roedl $\mathrm{S}$, Stockenhuber A. Are 1:4 mesh and donor site contraindications for vacuum-assisted closure device? J Trauma 2006; 61(5): 1267-70.

24. Sjögren J, Gustafsson R, Koul B, Ingemansson $\quad R$ Selective mediastinaltamponade to control coagulopathic bleeding. Ann ThoracSurg 2003; 75(4): 1311-3.

25. Thomas S. An introduction to the use of vacuum assisted closure. World Wide Wounds2001; 700(9): 72-9.
26. Bernstein B, Tam H. Combination of subatmospheric pressure dressing and gravity feed antibiotic instillation in the treatment of post-surgical diabetic foot wounds: A case series. Wounds 2005; 17(2): 37-48.

27. Farah R, Gantus M, Kogan L. Vacuumassisted therapy for various wound types including diabetic foot ulcer. Harefuah 2011; 150(3): 222-6.

28. Elshenawie HA, Ahmed Shalan W, Aziza E. Effect of ozone olive oil ointment dressing technique on the healing of superficial and deep diabetic foot ulcers. J Am Sci 2013; 9: 235-50.

29. Abd El Aziz AE, Eweda SMM, ElGamil AE, Kholosy HM. Effect of ozone therapy dressing technique on the healing process of recent $2^{\text {nd }}$ degree burns. IOSR-JNHS 2015; 4(4): 26-49.

30. National Institutes of Health (NIH), National Heart, Lung, and Blood Institute (NHLBI). Calculate your body mass index. Available at: http://www.nhlbi.nih.gov/health/educat ional/lose wt/BMI/bmicalc.htm.

(Accessed on: 18 Jan, 2016).

31. Aziza ES, Nahad E, Nabila B, Wael SH. Comparative study of ozonated olive oil ointment versus conventional dressing methods on the healing of grade I diabetic foot ulcers.Researcher2011; 3(8): 16-30.

32. Elder S, Alvarez OM, Dinh T. Local care of diabetic foot ulcer: assessment, dressings, and tropical treatments. In: Veves A, Giurini JM, LoGerfo FW (eds). The diabetic foot: medical and surgical management. New York: Humana Press; 2012: 289-306.

33. Sussman C, Bates-Jensen BM. Part I: Introduction to wound diagnosisWound healing physiology: acute and chronic. In: Sussman C, Bates-Jensen BM (eds). Wound care: a collaborative 
practice manual. Philadelphia: Lippincott Williams \& Wilkins; 2007: 21-50.

34. Johnston-Walker E, Hardcastle J. Neurovascular assessment in the critically ill patient. NursCrit Care 2011; 16(4): 170-7.

35. Boulton AJ, Armstrong DG, Albert SF, Frykberg RG, Hellman R, Kirkman MS, et al. Comprehensive foot examination and risk assessment: a report of the task force of the foot care interest group of the American Diabetes Association, with endorsement by the American Association of Clinical Endocrinologists. Diabetes Care 2008; 31(8): 1679-85.

36. Kotz S, Balakrishnan N, Read CB, Vidakovic B. Encyclopedia of statistical sciences. 2nd ed. Hoboken, N.J.: Wiley-Interscience; 2006.

37. Armstrong DG, Lavery LA. Negative pressure wound therapy after partial diabetic foot amputation: A multicenter randomized controlled trial. Lancet 2005; 366: 1704-10.

38. Blume PA, Walters J, Payne W, Ayala $\mathrm{J}$, Lantis J. Comparison of negative pressure wound therapy using vacuumassisted closure with advanced moist wound therapy in the treatment of diabetic foot ulcers: A multicenter randomized controlled trial. Diabetes Care 2008; 31: 631-6.

39. Tamhankar AP, Ravi K, Everitt NJ. Vacuum Assisted Closure ${ }^{\circledR}$ therapy in the treatment of mesh infection after hernia repair. Surgeons 2009; 7: 316-8.

40. Morykwas MJ, Argenta LC, SheltonBrown EI, McGuirt W. Vacuumassisted closure: A new method for wound control and treatment: Animal studies and basic foundation. Ann Plast Surg 1997; 38: 553-62.

41. Shrestha BM, Nathan VC, Delbridge MS, Parker K, Throssell D, McKane WS, et al. Vacuum-assisted closure (VAC) therapy in the management of wound infection following renal transplantation. Kathmandu Univ Med J 2007; 5:4-7.

42. McCallon SK, Knight CA, Valiulus JP, Cunningham MW, McCulloch JM, Farinas LP. Vacuum-assisted closure versus saline-moistened gauze in the healing of postoperative diabetic foot wounds. (34). Ostomy Wound Manage 2000; 46: 28-32.

43. Eginton MT, Brown KR, Seabrook GR, Towne JB, Cambria RA. A prospective randomized evaluation of negativepressure wound dressings for diabetic foot wounds. Ann Vasc Surg 2003; 17: 645-9.

44. Moues CM, Vos MC, van den Bemd GJ, Stijnen T, Hovius SE. Bacterial load in relation to vacuum-assisted closure wound therapy: A perspective randomized trial. Wound Repair Regen 2004; 12: 11-7.

45. Frykberg RG, Williams DV. NegativePressure Wound Therapy and Diabetic Foot Amputations. A Retrospective Study of Payer Claims Data. J Am Podiatr Med Assoc 2007; 97: 351-9.

46. Witkowski W, Jawien A, Witkiewicz $\mathrm{W}$, Zon B. Initial multi-centre observations upon the effect of a new Topical Negative Pressure device upon patient and clinician experience and the treatment of wounds. Int Wound J 2009; 6: 167-74. 